\title{
PENINGKATAN KEMAMPUAN GURU DALAM PENGEMBANGAN SILABUS DAN RPP DARING MELALUI POLA PEMBINAAN PROFESIONAL DENGAN PENDEKATAN KOOPERATIF DI SD NEGERI I KUMAI HULU SEMESTER 2 TAHUN PELAJARAN 20I9/2020
}

\author{
Improving Teachers 'Abilities In The Development Of Aaring Sylabus and RPP Through A Professional \\ Development Pattern With A Cooperative Approach In Sd Negeri I Kumai Hulu Semester 2 In \\ 2019/2020 Academic Year
}

\section{MUHAMAD HUSAINI, S.Pd SD}

NIP. 19690529199303 | 006

*,SD Negeri I Kumai Hulu, Kalimantan Tengah, Indonesia.

\section{Kata Kunci: \\ Program Kerja Nasional, Pembelajaran Jarak Jauh, Topic Perbincangan. \\ Keywords: \\ National Work Programs, Distance Learning, Conversation Topics.}

\section{Accepted}

September 2020

\section{Published}

December 2020

\begin{abstract}
Abstrak
Guru menjadi kunci hadirnya kualitas yang baik pada bidang pendidikan. Di tangan para guru yang mumpuni, siswa-siswi bisa mengembangkan diri secara optimal. Untuk itu, selain redistribusi guruguru unggul untuk pemerataan mutu sekolah di seluruh daerah, yang tak kalah penting ialah meningkatkan mutu seluruh guru yang ada.

Dampak dari pandemi corona di Indonesia, tahun 2020 ini merupakan tahun yang hampir semua program kerja nasional banyak yang tidak terlaksana, dalam dunia pendidikan diantaranya, UN ditiadakan US juga dengan alternatif pilihan disesuaikan dengan kemampuan sekolah masing masing, misalnya semua agenda kegiatan dihentikan belajar di rumah baik peserta didik, guru, pengawas madrasah dan kepala sekolah dari mulai tanggal 16 maret harus di rumah aja, agenda tahunan bagi peserta didik di jenjang SD, SMP dan SMAS/K semua di batalkan atas dasar penyelamatan manusia agar terhindar dari sang corona.
\end{abstract}

Saat minggu pertama belajar dirumah, kerja dirumah melakukan social distancing menjadi acuan dalam pelaksanaan pembelajaran jarak jauh (on line), semua kepala ramai berdiskusi membicarakan pakai apa, bagaimana, lalu bentuk materi dan tugas tugas apa yng harus diberikan kepada peserta didik yang tanpa harus berkelompok dan tidak juga harus keluar rumah. Setidaknya ini menjadi topic perbincangan di antara guru dalam grup Whatapp.

Berdasarkan kenyataan yang ada dilapangan bahwa di SD Negeri I Kumai Hulu yang merupakan tempat peneliti sebagai kepala sekolah. Kondisi guru-guru tersebut, para guru masih kesulitan dalam mengembangkan silabus dan RPP daring.

\footnotetext{
Abstract

Teachers are the key to the presence of good quality in the field of education. In the hands of qualified teachers, students can develop themselves optimally. For this reason, in addition to the redistribution of superior teachers to equalize the quality of schools throughout the regions, it is no less important to improve the quality of all existing teachers.
}

The impact of the corona pandemic in Indonesia, 2020 is a year in which almost all national work programs have not been implemented, in the world of education, among them, the UN was eliminated by the US as well as alternative choices adjusted to the ability of each school, for example all activity agendas were stopped studying at home both students, teachers, madrasah supervisors and school principals starting from March 16 must be at home alone, the annual agenda for students at the elementary, junior high and high school / $\mathrm{K}$ levels was all canceled on the basis of saving humans to avoid the corona.

During the first week of studying at home, working at home doing social distancing became a reference in implementing distance learning (on line), all the heads were busy discussing what to use, how, then what form of material and assignments should be given to students without having to be in groups and not also have to leave the house. At least this is a topic of conversation among teachers in the Whatapp group.

Based on the reality in the field, SD Negeri I Kumai Hulu is the place where the researcher is the principal of the school. The teacher's condition, the teachers still have difficulty in developing online syllabus and lesson plans. 


\section{PENDAHULUAN}

\section{KAJIAN TEORI DAN HIPOTESIS TINDAKAN}

\section{A. Kajian Teori}

A) Kajian Tentang Kemampuan Guru

\section{Hakekat Kemampuan}

Dalam Blog ian43 wordpress.com menyebutkan bahwa di dalam kamus bahasa Indonesia, kemampuan berasal dari kata "mampu" yang berarti kuasa (bisa, sanggup, melakukan sesuatu, dapat, berada, kaya, mempunyai harta berlebihan). Kemampuan adalah suatu kesanggupan dalam melakukan sesuatu. Seseorang dikatakan mampu apabila ia bisa melakukan sesuatu yang harus ia lakukan.

Kemampuan atau ability (kemampuan, kecakapan, ketangkasan, bakat, kesanggupan) merupakan tenaga (daya kekuatan) untuk melakukan suatu perbuatan. Sedangkan menurut Robbins kemampuan bisa merupakan kesanggupan bawaan sejak lahir, atau merupakan hasil latihan atau praktek.

Ada pula pendapat lain yang dikutip oleh lan43.wordpres.com yaitu pendapat menurut Akhmat Sudrajat menghubungkan kemampuan dengan kata kecakapan.

Setiap individu memiliki kecakapan yang berbeda-beda dalam melakukansuatu tindakan. Kecakapan ini mempengaruhi potensi yang ada dalam diri individu tersebut.

Menurut Mohammad Zain dalam Milman Yusdi (2010:10) mengartikan bahwa Kemampuan adalah kesanggupan, kecakapan, kakuatan kita berusaha dengan diri sendiri. Sedangkan Anggiat M.Sinaga dan Sri Hadiati dalam milmanyusdi.blogspot.com mendefenisikan kemampuan sebagai suatu dasar seseorang yang dengan sendirinya berkaitan dengan pelaksanaan pekerjaan secara efektif atau sangat berhasil.

\section{Hakekat Guru}

Dalam proses belajar mengajar guru adalah orang yang memberikan pelajaran. Dalam kamus bahasa Indonesia, guru diartikan "orang yang kerjanya mengajar". (Purwanarminta, 1984: 335) Guru adalah salah satu komponen manusiawi dalam proses belajar mengajar, yang ikut berperan serta dalam usaha pembentukan sumber daya manusia yang potensial di bidang pembangunan".

(Sardiman, 200I:123) Guru adalah semua orang yang berwenang dan bertanggung jawab terhadap pendidikan murid-murid, baik secara individual maupun secara klasikal, baik di sekolah maupun di luar sekolah" (Djamarah, 1994:33). Pada sisi lain , Djamarah berpendapat "guru adalah semua orang yang berwenang dan bertanggung jawab untuk membimbing dan membina anak didik, baik secara individual maupun klasikal di sekolah maupun di luar sekolah" (Djamarah, 2000:32).

Latar belakang pendidikan seorang guru dari guru lainnya terkadang tidak sama dengan pengalaman pendidikan yang pernah dimasuki selama jangka waktu tertentu. Perbedaan latar belakang pendidikan akan mempengaruhi kegiatan guru dalam melaksanakan kegiatan interaksi belajar mengajar. Tetapi, karena banyaknya guru yang dibutuhkan di madrasahmadrasah atau sekolah maka latar belakang pendidikan seseorang seringkali tidak dipertimbangkan.

\section{Kemampuan Guru}

Kemampuan guru dapat dartikan sebagai Kompetensi Guru "Kompetensi berasal dari bahasa inggris, yakni "Competency" yang berarti kecakapan, kemampuan. Menurut kamus besar bahasa Indonesia, kompetensi adalah kewenangan (kekuasaan) untuk menentukan (memutuskan) sesuatu" (Djamarah, 1994 : 33).

Kalau kompetensi berarti kemampuan atau kecakapan, maka hal ini erat kaitannya dengan pemilikan pengetahuan, kecakapan atau keterampilan sebagai guru. Dengan demikian, tidaklah berbeda dengan kemampuan kompetensi yang dikemukakan oleh abdul kadir Munsyi (1994 : 33).Yang mengatakan bahwa "Kompetensi sebagai suatu tugas yang memadai atau memiliki pengetahuan, keterampilan dan kemampuan yang dituntut oleh jabatan seseorang".

Terkait dengan pendapat di atas, Ametembun (1994 :33) megemukakan bahwa "Guru adalah semua orang yang berwenang dan bertanggung jawab terhadap pendidikan murid-murid, baik secara individual maupun klasikal, baik di sekolah maupun luar sekolah". Ini berarti bahwa seorang guru, minimal harus memiliki dasar-dasar kompetensi sebagai wewenang dan kemampuan dalam menjalankan tugas. Berdasarkan uraian di atas, dapatlah dipahami bahwa kompetensi guru merupakan suatu kemampuan yang mutlak dimiliki oleh seorang guru, baik dari segi pengetahuan, keterampilan dan kemampuan serta tanggung jawab terhadap murid-murid yang di asuhnya,sehingga tugasnya sebagai seorang pendidik dapat terlaksana dengan baik.

Untuk mendapat pengertian dan pengetahuan mengenai kompetensi guru ini, pembahasan berikut akan membahas sepuluh kompetensi propesional guru yang harus dimiliki dan bahkan dikuasi dalam dalam rangka menjalankan tugasnya sebagai pengajar.

B) Pengembangan Silabus dan RPP daring 
Di masa depan keberlangsungan, kebergunaan dan kebermaknaan pendidikan kita akan ditentukan oleh kemampuannya serta fleksibelitas kiya dalam merespons hal-hal yang tak terduga. Pandemi Covid-19 salah satunya. Kurikulum 2013 misalnya tidak dirumuskan untuk menghadapi pandemi Covid-19 di tahun 2020.

Pendidikan butuh kurikulum yang fleksibel, Pendidikan butuh skenario pembelajaran (silabus, lesson plan) yang fleksibel, multi-skenario pembelajaran, Pendidikan butuh pedagogi yang fleksibel, sejenis multimodal pedagogy-atau apapaun namanya itu, kita butuh assessment yang juga fleksibel dengan tanpa mengurangi kualitas, agar di saat-saat tertentu ketika muncul hal-hal tak terduga yang tak terprediksi (bencana, konflik, riots), pendidikan akan tetap berlangsung. Tentu saja dengan tetap harus mengutamakan manusia di atas kurikulum, metode, media, dan teknis assessment apapun itu.

Pendidikan yang telanjur menjadi birokrasi gemuk dengan mata rantai komunikasi dan koordinasi yang teramat panjang dan tidak efektif. Seperti sekarang, sekolah-sekolah, guru-guru, dan bahkan kampus kelimpungan menjalankan pembelajaran jarak jauh alias dalam jaringan (daring). Banyak yang lamban bergerak karena menunggu instruksi Pusat, menunggu surat edaran Dinas, dan lainnya. Beruntung embrio pembelajaran berjejaring dan personal sudah dikenalkan sejak kira-kira 10 tahun terakhir.

Yang harus di lakukan adalah:

Pertama, perpanjang masa pengerjaan tugas. $\mathrm{Hal}$ ini penting, mengingat siswa perlu beradaptasi dengan ritme belajar baru, juga cara belajar baru yang lebih menekankan pada kemandirian belajar. Kondisi pandemi, harus melakukan physical distance, tentu membuahkan tekanan, kebosanan, dan ritme hidup baru. Namun, belajar jarak jauh-termasuk daring di dalamnya-juga tidak mungkin tanpa memberi tugas sama sekali. Karena dari tugas itulah guru tahu capaian hasil belajar siswanya.

Kedua, fokus pada unjuk kerja (kinerja) atau produk yang menjadi ukuran dari keberhasilan capaian belajar siswa. Tidak perlu mengontrol ketat pemahaman per sub-bahasan, karena akan cenderung memberi tugas berlebih-dan ini yang rata-rata terjadi di banyak sekolah sekarang. Kalau tujuan pembelajarannya berupa pemahaman, cukup diberikan I atau 2 tugas terkait dengan tujuan tersebut. Tujuan pembelaran di sini maksudnya tujuan pembelajaran dalam I semester, bukan I pertemuan/topik. Tidak perlu rinci. Tinggal guru memastikan pemahamannya tepat dengan eksplorasi tugas tersebut saja.
Ketiga, pegang kompetensi inti (KI) saja, tidak perlu kompetensi dasar (KD). Di semua sekolah yang menjalankan Kurikulum 2013 sekarang yang dipegang adalah KD. Nah, KD ada banyak dan merupakan penjabaran dari KI. Berpegang pada KD akan cenderung memaksa guru untuk memberikan banyak pelajaran secara detail, padahal sejatinya $\mathrm{KI}$ yang dituju cukup padat dan ringkas. Nah, $\mathrm{Kl}$ ini saja yang dipegang hingga nanti pembelajarannya tidak akan "terlalu rinci dan detail" sebagaimana sekarang ketika memegang ketat KD. Dengan berpegang pada KI saja, materi lebih ringkas, pembelajaran dapat dirancang ulang lebih ringkas/sederhana tapi tetap sesuai KI. Akhirnya tugas juga ringkas. Penilaian seperti di point nomor 2, fokus saja pada kinerja dan produk.

Sayang rumusan KI dalam Kurikulum 2013 terlalu abstrak. Hingga guru pasti kesulitan ketika hanya memegang $\mathrm{KI}$ sebagai acuan merumuskan pembelajaran. Oleh karena itu, baca ulang KD-KD (lihat di Permendikbud No. 24/2016) sesuai mata pelajaran dan jenjang masing-masing. Buat list/daftar inti-inti kompetensi yang hendak dipakai apa, dan daftar ini jadikan sebagai acuan merancang ulang pembelajaran dan penilaian hasil belajar. Jika daftar inti-inti kompetensi hasil pembacaan atas KD-KD ini concise betul (ringkas), maka sejatinya inilah $\mathrm{KI}$ yang sebetulnya.

Sejatinya, arah pembelajaran yang langsung to the point (intinya mau bisa apa ini), tanpa melakukan pembelajaran yang bertele-tele dan buang-buang waktu—sementara di keseharian siswa, guru, dan orang tua sedang menghadapi pandemi Covid-19, merupakan pengingat pada hal paling fundamental dalam pendidikan, yakni: tujuan pendidikan, tujuan belajar. $\mathrm{Hal}$ ini di era digital sekarang tampaknya mulai disadari dan banyak yang berani melakukan. Misal, mau bisa masak, tinggal ikut kursus masak, jika bisa daring ya ikut daring saja, lebih ringkas, mudah, murah. Tak perlu sekolah tata boga atau kuliah tata boga, yang lama waktunya, bayarnya juga lumayan.

Tujuan inti pendidikan, tujuan inti belajar ini yang harus disadari dan dipegang oleh guru/dosen. Karena akan sangat mencerahkan dan menyadarkan bahwa sejatinya barangkali strategi pembelajaran kita tak perlu bertele-tele dan berseri-seri banyaknya. Ini tantangan bagi sekolah dan kampus formal kita sekarang. Bisakah bertahan di tengah lahirnya pusat-pusat belajar baru dalam bentuk MOOCs (misal Coursera, Alison, EdX, Icourse, Future Learn), komunitas belajar, homeschooling, atau bahkan channel-channel YouTube, instagram, twitter, WA, dan Facebook.

C) Pola Pembinaan Profesional Dengan Pendekatan Kooperatif 


\section{Pengertian Pembinaan Guru}

Secara etimologis pembinaan guru sering diartikan sebagai serangkaian usaha bantuan yang diberikan kepada guru dalam wujud bantuan layanan profesional yang dilakukan oleh kepala sekolah, penilik sekolah dan pengawas serta pembina lainnya guna meningkatkan kualitas proses belajar mengajar. Istilah pembinaan guru sebenarnya berasal dari kurikulum SD, SMP, dan SMA tentang pembinaan guru (Depdikbud, 1984; 1986).

Sedangkan secara terminologis pembinaan guru sering diartikan sebagai serangkaian usaha bantuan guru, terutama bantuan yang berwujud layanan profesional yang dilakukan oleh kepala sekolah, pengawas, serta pembina lainnya guna meningkatkan proses dan hasil belajar di sekolah (Ali Imron, 1995: 9).

Pembinaan dalam Kamus Besar Bahasa Indonesia (Tim penyusun Kamus Besar Bahasa Indonesia, 2005: 152), "pembinaan adalah proses, cara, perbuatan membina, pembaharuan, penyempurnaan, dan usaha, tindakan dan penyempurnaan, dan usaha, tindakan dan kegiatan yang dilakukan secara efektif dan efisien untuk memperoleh hasil yang terbaik." Dalam kepustakaan asing dan Indonesia istilah pembinaan sering disebut juga dengan supervisi.

Enco Mulyasa (2002: 2I) pembinaan merupakan serangkaian upaya pengendalian profesional terhadap semua unsur organisasi agar unsur-unsur organisasi dapat berfungsi sebagaimana mestinya sehingga rencana untuk mencapai tujuan dapat terlaksana secara efektif dan efisien. Pembinaan merupakan aktivitas peningkatan kualitas yang multidimensional bersifat pelestarian, perbaikan, pembaharuan, serta pengembangan progresif.

\section{Tujuan Pembinaan Guru}

Tujuan pembinaan guru menurut Ali Imron (1995: 12) merupakan usaha untuk meningkatkan kemampuan profesional guru dalam meningkatkan proses dan hasil belajar melalui pemberian bantuan yang bercorak layanan profesional kepada guru. Dengan adanya pembinaan guru akan memperlancar pencapaian tujuan kegiatan belajar mengajar.

Menurut Djajadisastra yang dikutip oleh Ali Imron (1995: 12) menjelaskan tujuan dari pembinaan guru sebagai berikut :

a. Memperbaiki tujuan khusus mengajar guru dan belajar siswa

b. Memperbaiki materi (bahan) dan kegiatan belajar mengajar

c. Memperbaiki metode yaitu dengan cara mengorganisasikankegiatan belajar mengajar d. Memperbaiki penilaian atas media

e. Memperbaiki penilaian proses belajar mengajar dan hasilnya

f. Memperbaiki pembimbingan siswa atas kesulitas belajarnya

g. Memperbaiki sikap guru atas tugasnya.

\section{Teknik Pembinaan Guru}

Suharsimi Arikunto (2004: 53) teknik supervisi guru dibedakan menjadi dua macam alat atau teknik sebagai berikut:

a. Teknik yang bersifat individu

Teknik individu atau perseorangan adalah bantuan yang dilakukan secara sendiri oleh petugas supervisi, baik terjadi di dalam kelas maupun di luar kelas. Teknik ini terdiri dari: mengadakan kunjungan kelas, mengadakan observasi kelas, mengadakan wawancara perseorangan, dan mengadakan wawancara kelompok.

b. Teknik kelompok

Teknik secara kelompok terdiri dari: mengadakan pertemuan atau rapat, mengadakan diskusi kelompok, mengadakan penataran-penataran, dan seminar.

Menurut Piet Sahertian dan Frans Mataheru (1986) mengemukakan teknik sueprvisi pendidikan yang dikutip oleh Hartati Sukirman, dkk (2009: 102) sebagai berikut:

I) Teknik yang bersifat individu mencakup: kunjungan kelas, observasi kelas, percakapan pribadi, saling mengunjungi kelas, dan menilai diri sendiri.

2) Teknik yang bersifat kelompok mencakup: pertemuan orientasi guru baru, panitia penyelenggara, rapat guru, studi kelompok antar guru, diskusi kelompok, tukar menukar pengalaman, lokakarya, diskusi panel, seminar, simposium, demonstration teaching, perpustakaan jabatan, bulletin supervisi, membaca langsung, mengikuti kursus, organisasi jabatan, perjalanan sekolah, dan curriculum laboratory.

\section{Jenis Kegiatan Pembinaan Guru}

Menurut Depdikbud (1997: 5) bahwa pembinaan profesional adalah usaha yang dilakukan kepala sekolah atau kepala sekolah dalam memberikan bantuan kepada guru untuk dapat meningkatkan kemampuan profesionalnya dalam mengajar dan menambah wawasan ilmu pengetahun sehingga menghasilkan guru yang profesional dalam mengelola pembelajaran di kelas.

Agar tugas, peranan, dan tanggung jawab guru selalu up-to date maka secara terus menerus kepala sekolah mengupayakan guru agar selalu mengembangkan kompetensinya dengan mengikuti 
berbagai macam kegitan guna mendukung dalam tugas mengajarnya. Peningkatan profesional guru secara terus menerus hendaknya dilakukan dengan cara pembinaan dan pengembangan profesi dan karier. Menurut Undang-undang Nomor 14 Tahun 2005 tentang Guru dan Dosen Pasal 32 ayat I menyatakan bahwa pembinaan dan pengembangan profesi guru yakni:

a. Pembinaan dan pengembangan profesi dan karier.

b. Pembinaan dan pengembangan guru sebagaimana dimaksud pada ayat I meliputi kompetensi pedagogik, kompetensi kepribadian, kompetensi sosial, dan kompetensi profesional.

c. Pembinaan dan pengembangan guru sebagaimana dimaksud pada ayat I dilakukan melalui jabatan fungsional.

d. Pembinaan dan pengembangan guru sebagaimana dimaksud pada ayat I meliputi penugasan, kenakikan pangkat dan promosi.

\section{B. Penelitian Yang Relevan}

Berikut adalah beberapa hasil penelitian yang relevan dengan penelitian tindakan sekolah ini:

I. Jurnal dengan judul "UPAYA MENINGKATKAN KOMPETENSI GURU DALAM PENGEMBANGAN SILABUS DAN RPP MELALUI PEMBINAAN PROFESIONAL KEPALA SEKOLAH DENGAN PENDEKATAN KOPERATIF Oleh: Riduwan, Hasil penelitian menunjukkan adanya peningkatan kompetensi guru dalam pengembangan silabus dan perencanaan pelaksanaan pembelajaran meningkat yakni dari nilai rata-rata dari 50,88 dengan kriteria nilai kurang pada Pra Siklus, menjadi 69,19 kriteria nilai cukup pada siklus pertama dan menjadi 90,13 kriteria nilai sangat baik pada siklus kedua, dengan rata-rata klasikal sebesar 70,07 dengan kriteria nilai baik. Kesimpulannya adalah pembinaan profesional dengan pendekatan kooperatif dapat meningkatkan kompetensi guru-guru dalam pengembangan silabus dan RPP di SDN 050769 Sei Bilah kecamatan Sei Lepan kabupaten Langkat.

\section{Kerangka Berfikir}

Kerangka Berpikir adalah sebuah model atau gambaran yang berupa konsep yang didalamnya menjelaskan tentang hubungan antara variabel yang satu dengan varibel yang lainnya.
Oleh sebab itu, sebaiknya kerangka berpikir ini dibuat dalam bentuk diagram atau skema, dengan tujuan untuk mempermudah memahami beberapa variabel data yang akan dipelajari pada tahap selanjutnya.

\section{Hipotesis Tindakan}

Hipotesis diartikan sebagai dugaan sementara pada penelitian yang akan dilakukan. Termasuk dalam pelaksanaan penelitian tindakan kelas, hipotesis dibutuhkan sebagai acuan peneliti, yang disebut dengan hipotesis tindakan.

Hipotesis tindakan dalam penelitian ini adalah pola pembinaan profesional dengan pendekatan kooperatif dapat meningkatkan kemampuan guru dalam pengembangan silabus dan RPP daring di SD Negeri I Kumai Hulu.

\section{METODE PENELITIAN}

\section{A. Pendekatan Penelitian}

Penelitian ini merupakan penelitian tindakan sekolah (School Action Research), karena penelitian dilakukan untuk memecahkan masalah proses pembelajaran di sekolah. Penelitian ini menggambarkan bagaimana suatu teknik pembelajaran diterapkan dan bagaimana hasil yang diinginkan dapat dicapai. Penelitian ini mengambil bentuk penelitian tindakan sekolah (PTS) yaitu peningkatan kinerja guru melalui kunjungan kelas dalam rangka mengimplementasikan standar proses, yang terdiri dari 2 siklus dan masing- masing siklus terdiri dari 4 tahap yaitu :
(I) tahap perencanaan program tindakan,
(2) pelaksanaan program tindakan,
(3) pengamatan program,
(4) refleksi.

\section{B. Tempat dan Waktu Penelitian}

\section{Tempat Penelitian}

Penelitian ini akan dilaksanakan di SD Negeri I Kumai Hulu. Pemilihan tempat ini di mana penulis bertugas sebagai kepala sekolah di SD Negeri I Kumai Hulu.

\section{Waktu Penelitian}

Penelitian akan dilakukan pada semester genap tahun 2020 di SD Negeri I Kumai Hulu. Berikut adalah jadwal kegiatan dan waktu penelitian:

Tabel I Jadwal Kegiatan Dan Waktu Penelitian

\begin{tabular}{|c|c|c|c|c|c|c|c|c|c|c|c|c|c|c|c|c|c|}
\hline \multirow[t]{2}{*}{ No } & \multirow[t]{2}{*}{ Kegiatan } & \multicolumn{4}{|c|}{$\begin{array}{l}\text { Januari } \\
\text { Minggu ke }\end{array}$} & \multicolumn{4}{|c|}{$\begin{array}{l}\text { Februari } \\
\text { Minggu ke }\end{array}$} & \multicolumn{4}{|c|}{$\begin{array}{l}\text { Maret } \\
\text { Minggu ke }\end{array}$} & \multicolumn{4}{|c|}{$\begin{array}{l}\text { April } \\
\text { Minggu ke }\end{array}$} \\
\hline & & $\mathrm{I}$ & 2 & 3 & 4 & $\mathrm{I}$ & 2 & 3 & 4 & $\mathrm{I}$ & 2 & 3 & 4 & 1 & 2 & 3 & 4 \\
\hline $\mathrm{I}$ & Observasi awal & & $\sqrt{ }$ & $\sqrt{ }$ & & & & & & & & & & & & & \\
\hline 2 & Wawancara dengan & & & & $\sqrt{ }$ & & & & & & & & & & & & \\
\hline
\end{tabular}




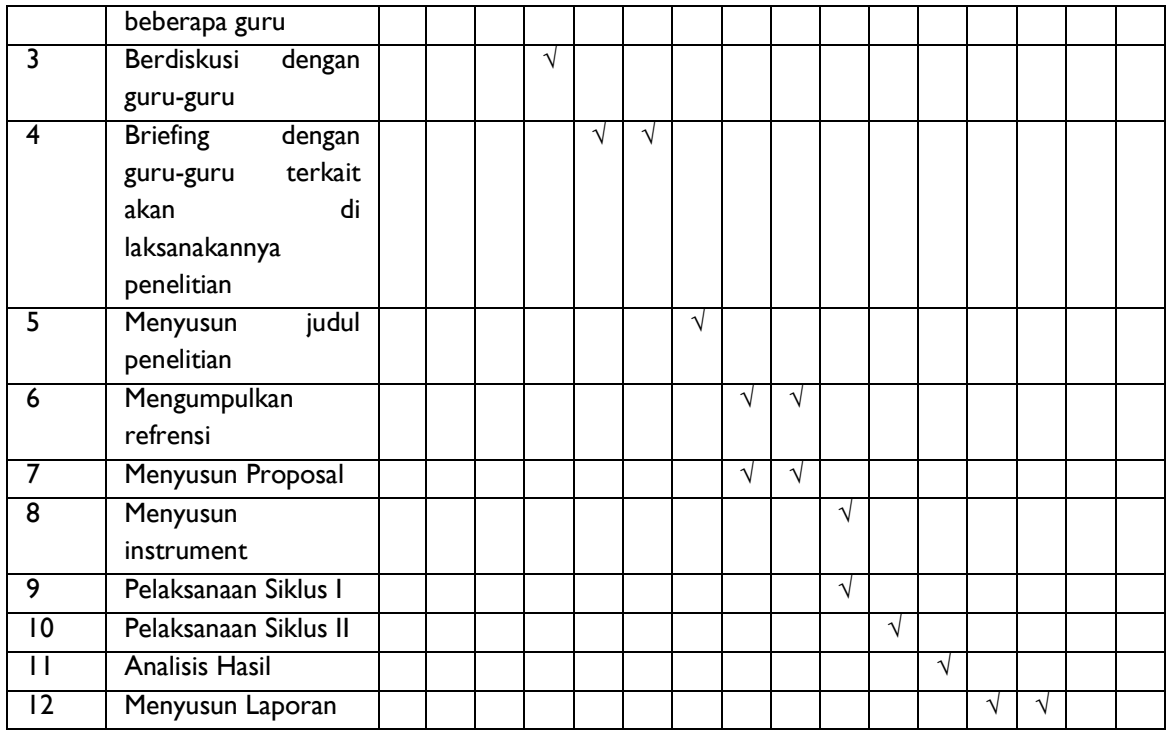

\section{Subjek Penelitian}

Penelitian ini dilaksanakan di SD Negeri I Kumai Hulu dengan subjek penelitian adalah guru yang ada di sekolah ini, baik yang sudah pegawai negeri sipil maupun yang masih wiyata bakti. Berikut adalah subjek penelitian ini:

Tabel 2 Subjek Penelitian

\begin{tabular}{|c|l|}
\hline NO & \multicolumn{1}{|c|}{ NAMA GURU } \\
\hline I & Awun \\
\hline 2 & Suslen \\
\hline 3 & Masniyah \\
\hline 4 & Umi Kalsum \\
\hline 5 & Anis Soini \\
\hline 6 & Yunina Novarita \\
\hline 7 & Amrullah \\
\hline 8 & Reny Alfionita \\
\hline 9 & Evi Saputri \\
\hline 10 & Dwi Suryanti \\
\hline
\end{tabular}

\section{Prosedur Penelitian}

\section{Siklus I}

a. Perencanaan

Pada tahap ini peneliti merumuskan dan mempersiapkan: rencana jadwal pelaksanaan tindakan, rencana pelaksanaan pola pembinaan profesional dengan pendekatan kooperatif, membuat lembar observasi, dan mempersiapkan kelengkapan lain yang diperlukan dalam rangka analisis data.

b. Tahap Pelaksanaan

Pelaksanaan pola pembinaan profesional dengan pendekatan kooperatif Siklus I dilaksanakan selama $2 \mathrm{X}$ pertemuan dalam seminggu. Pelaksanaan tindakan pada dasarnya disesuaikan dengan setting tindakan yang telah ditetapkan dalam rencana pelaksanaan.

c. Pengamatan

Setelah proses bembinaan kedisiplinan selesai maka dilakukan pengamatan selama seminggu terhadap guru. Pengamatan dilakukan untuk mengetahui peningkatan kemampuan guru dalam pengembangan silabus dan RPP daring

\section{d. Refleksi}

Refleksi merupakan kegiatan menganalisis semua data atau informasi yang dikumpulkan dari penelitian tindakan yang dilaksanakan, sehingga dapat diketahui berhasil atau tidaknya tindakan yang telah dilaksanakan dengan tujuan yang diharapkan.

\section{E. Teknik Pengumpulan Data}

Pengumpulan data dalam penelitian ini menggunakan tiga teknik yaitu :

\section{Wawancara}

Wawancara merupakan merupakan sebuah percakapan langsung antara si peneliti dengan responden yang diteliti yang dilakukan dengan tujuan untuk memperoleh informasi yang dibutuhkan. Dalam penelitian inti peneliti menggunakan pedoman 
wawancara yang sifatnya terbuka yang dimaksudkan agar peneliti tidak keluar dari apa yang sedang diteliti.

Untuk lebih memantapkan hasil wawancara peneliti melakukan cross check dengan melakukan wawancara selain dengan kepala sekolah juga dengan guru.

\section{Observasi}

Observasi adalah pengamatan dan pencatatan yang sistematis terhadap gejala- gejala yan diteliti (Husaini Usman dan Purnomo Setiady Akbar, 200I: 54). Dari pengertian tersebut sudah jelas bahwa observasi merupakan pengamatan langsung terhadap suatu kegiatan yang sedang dilakukan. Sehingga, dalam penelitian ini peneliti melakukan pengamatan secara langsung terhadap kemampuan guru dalam pengembangan silabus dan RPP daring. Teknik ini digunakan untuk mendapatkan data yang cermat dan faktual.

Obsevasi ini dilakukan secara berkelanjutan dengan memperhatikan situasi dan kondisi yang terjadi di sekolah tersebut, sehingga akan diperoleh informasi yang sesuai dengan kebutuhan peneliti.

\section{Studi dokumentasi}

Penelitian kualitatif selain menggunakan observasi dan wawancara dalam mencari sumber data, tetapi masih perlu dilakukan dengan studi dokumentasi yang dilakukan dengan melihat, mengamati dan menganalisis dokumen-dokumen agar mampu menguatkan hasil yang diperoleh dengan melakukan obsevasi dan wawancara. Peneliti melakukan studi dokumentasi untuk dimanfaatkan sebagai bahan triangulasi untuk pengecekan kesesuaian data.

\section{F. Instrumen Penelitian}

Menurut Nurul Zuriah (2007: 168) dikatakan bahwa instrumen penelitian merupakan alat bantu bagi peneliti dalam mengumpulkan data. Dalam melakukan penelitian, seorang peneliti harus mampu membuat instrumen sendiri termasuk mengkaji indikator sejelasjelasnya sehingga bisa diukur dan menghasilkan data yang diinginkan. Instruman yang digunakan peneliti dalam melakukan penelitian kualitatif adalah si peneliti itu sendiri sebab dibutuhkan pengamatan langsung oleh peneliti untuk melihat objek di lapangan. Sehingga, peneliti bisa melakukan pengamatan secara mendalam.

Dalam penelitian ini peneliti menggunakan instrumen penelitian dengan wawancara, observasi dan studi dokumentasi.

\section{HASIL PENELITIAN DAN PEMBAHASAN}

\section{A. Hasil Penelitian}

\section{Hasil Penelitian Pra Tindakan}

Penelitian ini dilaksanakan di SD Negeri I Kumai Hulu dengan subjek penelitian adalah guru yang ada di sekolah ini, baik yang sudah pegawai negeri sipil maupun yang masih wiyata bakti. Adapun kemampuan guru dalam pengembangan silabus dan RPP daring yang ada di SD Negeri I Kumai Hulu adalah sebagai berikut:

Berikut adalah hasil pembinaan pra tindakan tentang kemampuan guru dalam pengembangan silabus dan RPP daring

\section{Tabel 3}

Data Hasil Penilaian Kemampuan Guru dalam Pengembangan Silabus Daring Pra Tindakan

Penilai : MUHAMAD HUSAINI, S.Pd SD

Petunjuk: Penilai memberi nilai dan isikan pula secara jelas hal-hal penting/menarik pada saat penelitian

\begin{tabular}{|c|c|c|c|c|c|c|c|}
\hline \multirow[t]{2}{*}{ No } & \multirow[t]{2}{*}{ Guru } & \multicolumn{4}{|c|}{$\begin{array}{l}\text { Aspek } \\
\text { dinilai }\end{array}$} & \multirow[t]{2}{*}{$\begin{array}{l}\text { Jml } \\
\text { Skor }\end{array}$} & \multirow[t]{2}{*}{ Kategor } \\
\hline & & $\mathrm{I}$ & 2 & 3 & 4 & & \\
\hline 1 & Awun & 1 & 2 & 1 & 1 & 5 & B \\
\hline 2 & Suslen & 1 & 1 & 1 & 1 & 4 & C \\
\hline 3 & Masniyah & $\mathrm{I}$ & 1 & $T$ & 1 & 4 & $\mathrm{C}$ \\
\hline 4 & Umi Kalsum & $\mathrm{I}$ & $\mathrm{I}$ & $T$ & $\mathrm{I}$ & 4 & $C$ \\
\hline 5 & Anis Soini & $\mathrm{I}$ & $\mathrm{T}$ & $T$ & $T$ & 4 & $\mathrm{C}$ \\
\hline 6 & Yunina Novarita & $\mathrm{I}$ & $\mathrm{T}$ & $T$ & $\mathrm{I}$ & 4 & $\mathrm{C}$ \\
\hline 7 & Amrullah & $\mathrm{I}$ & $\mathrm{I}$ & 1 & $\mathrm{I}$ & 4 & C \\
\hline 8 & Reny Alfionita & $\mathrm{I}$ & $\mathrm{T}$ & $T$ & $T$ & 4 & $\mathrm{C}$ \\
\hline 9 & Evi Saputri & $\mathrm{I}$ & $\mathrm{I}$ & 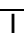 & $\mathrm{I}$ & 4 & $\mathrm{C}$ \\
\hline 10 & Dwi Suryanti & $\mathrm{I}$ & $\mathrm{T}$ & $\mathrm{T}$ & $\mathrm{T}$ & 4 & C \\
\hline
\end{tabular}

Keterangan: 


\begin{tabular}{|l|l|}
\hline No & \multicolumn{1}{|c|}{ Aspek yang dinilai } \\
\hline I & $\begin{array}{l}\text { Guru menyusun silabus dengan format yang terdiri dari 9 aspek yaitu } \\
\text { mapel, KD, kegiatan pembelajaran, sumber belajar, penilaian, jenis } \\
\text { daring, alokasi waktu, ketercapaian pembelajaran, dan kendala }\end{array}$ \\
\hline 2 & $\begin{array}{l}\text { Pada aspek kegiatan pembelajaran, guru mampu menyusun kegiatan } \\
\text { berupa pembelajaran dengan moda daring }\end{array}$ \\
\hline 3 & $\begin{array}{l}\text { Pada aspek jenis daring guru mampu mencantumkan jenis aplikasi yang } \\
\text { di gunakan dalam moda daring }\end{array}$ \\
\hline 4 & Guru mampu menyusun silabus daring secara sistematis \\
\hline
\end{tabular}
A : Amat Baik (Skor 3)
B: Baik (Skor 2)
C: Cukup (Skor I)

Skor Maksimal: 3X 4= 12

Kriteria Penilaian

A: 9-12 : Kemampuan guru dalam pengembangan silabus daring Amat Baik

B:5-8 : Kemampuan guru dalam pengembangan silabus daring Baik

$\mathrm{C}: \leq 4$ : Kemampuan guru dalam pengembangan silabus daring Cukup

Sedangkan penilaian kemampuan guru dalam pengembangan silabus dan RPP daring pada pra siklus didapatkan hasil sebagai berikut:

Tabel 4

Data Hasil Penilaian Kemampuan Guru dalam Pengembangan RPP daring Pra Tindakan

\begin{tabular}{|c|c|c|c|c|c|c|}
\hline \multirow[t]{2}{*}{ No } & \multirow[t]{2}{*}{ Nama Guru } & \multicolumn{4}{|c|}{ Aspek yang di nilai } & \multirow[t]{2}{*}{ Kategori } \\
\hline & & $\mathrm{I}$ & 2 & 3 & 4 & \\
\hline $\mathrm{I}$ & Awun & $\mathrm{T}$ & $\mathrm{I}$ & $\mathrm{T}$ & $\mathrm{I}$ & C \\
\hline 2 & Suslen & $\mathrm{I}$ & I & I & I & $\mathrm{C}$ \\
\hline 3 & Masniyah & $\mathrm{I}$ & $\mathrm{I}$ & $\mathrm{I}$ & $\mathrm{I}$ & $\mathrm{C}$ \\
\hline 4 & Umi Kalsum & $\mathrm{I}$ & $\mathrm{T}$ & $\mathrm{T}$ & $\mathrm{I}$ & $\mathrm{C}$ \\
\hline 5 & Anis Soini & $\mathrm{I}$ & $T$ & $\mathrm{~T}$ & $\mathrm{~T}$ & $\mathrm{C}$ \\
\hline 6 & Yunina Novarita & $\mathrm{I}$ & I & 1 & I & C \\
\hline 7 & Amrullah & $\mathrm{I}$ & $\mathrm{I}$ & $\mathrm{I}$ & $\mathrm{I}$ & $C$ \\
\hline 8 & Reny Alfionita & $\mathrm{I}$ & $T$ & $\mathrm{I}$ & $\mathrm{I}$ & $\mathrm{C}$ \\
\hline 9 & Evi Saputri & $\mathrm{I}$ & $\mathrm{T}$ & $\mathrm{I}$ & $\mathrm{I}$ & $\mathrm{C}$ \\
\hline 10 & Dwi Suryanti & $\mathrm{I}$ & $\mathrm{I}$ & $\mathrm{I}$ & $\mathrm{I}$ & $C$ \\
\hline \multicolumn{2}{|c|}{ Skor $\mathrm{F}$} & $\mathrm{I}, 2$ & $\mathrm{~T}$ & $\mathrm{~T}$ & $\mathrm{I}$ & \\
\hline
\end{tabular}

Keterangan:

\begin{tabular}{|l|l|}
\hline No & \multicolumn{1}{|c|}{ Aspek yang dinilai } \\
\hline I & $\begin{array}{l}\text { Guru menyusun RPP dengan format yang terdiri dari 8 aspek yaitu KD, } \\
\text { Indikator, Tujuan pembelajaran, materi pembelajaran, model } \\
\text { pembelajaran, Alat, bahan dan media, langkah kegiatan dan penilaian }\end{array}$ \\
\hline 2 & $\begin{array}{l}\text { Pada aspek langkah kegiatan, guru mampu menyusun kegiatan berupa } \\
\text { pembelajaran dengan moda daring }\end{array}$ \\
\hline 3 & $\begin{array}{l}\text { Pada aspek penilaian guru mampu menyusun instrument penilaian yang } \\
\text { di gunakan dalam moda daring }\end{array}$ \\
\hline 4 & Guru mampu menyusun RPP daring secara sistematis \\
\hline
\end{tabular}

A : Amat Baik (Skor 3)

B: Baik (Skor 2)

C: Cukup (Skor I)

Skor Maksimal: $3 \times 4=12$

Kriteria Penilaian
A: 9-12: Kemampuan guru dalam pengembangan RPP daring Amat Baik

B:5-8 : Kemampuan guru dalam pengembangan RPP daring Baik

$C: \leq 4$ : Kemampuan guru dalam pengembangan RPP daring Cukup 


\section{Diagram I Hasil Penilaian Kemampuan Guru dalam Pengembangan RPP daring Pra}

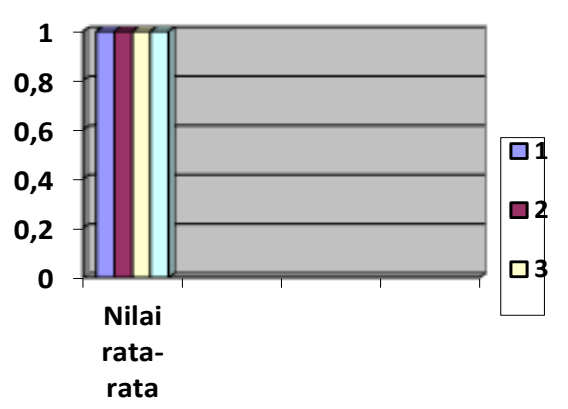

\section{Pelaksanaan Siklus I}

\section{a. Tahap Perencanaan}

Pada perencanaan, peneliti melaksanakan program pola pembinaan profesional dengan pendekatan kooperatif dalam meningkatkan kemampuan guru dalam pengembangan silabus dan RPP daring.

Pada tahap perencanaan peneliti menyiapkan hal berikut:

$\square$ Rencana jadwal pelaksanaan tindakan,

$\square$ Rencana pelaksanaan pola pembinaan profesional dengan pendekatan kooperatif,

$\square$ Membuat lembar observasi, dan

$\square$ Mempersiapkan kelengkapan lain yang diperlukan dalam rangka analisis data.

\section{b. Tahap Pelaksanaan}

Adapun pelaksanannya adalah sebagai berikut:

$\square$ Peneliti melakukan apersepsi

$\square$ Peneliti membimbing guru menyusun silabus dan RPP daring.

$\square$ Peneliti menyampaikan tujuan yang akan dicapai

Peneliti mempresentasikan materi tentang silabus dan rencana pelaksanaan pembelajaran

$\square$ Guru bekerja secara kelompok

$\square$ Guru berdiskusi untuk menyusun silabus dan RPP

Guru pada tiap kelompok menyaiikan hasil kerja kelompok

\section{c. Pengamatan}

Setelah kegiatan pola pembinaan profesional dengan pendekatan kooperatif berlangsung, peneliti bertindak sebagai supervisor yang bertugas mengamati kemampuan guru dalam pengembangan silabus dan RPP daring dengan mengisi lembar penilaian yang telah disusun sebelum melaksanakan kegiatan penelitian. Hal ini dilakukan untuk mengetahui peningkatan
Siklus

kemampuan guru dalam pengembangan silabus dan RPP daring.

Berikut adalah hasil pembinaan siklus I:

Tabel 5

Data Hasil Penilaian Kemampuan Guru dalam Pengembangan Silabus daring Siklus I

Penilai : MUHAMAD HUSAINI, S.Pd SD

Petunjuk: Pennilai memberi nilai dan isikan pula secara jelas hal-hal penting/menarik pada saat penelitian 


\begin{tabular}{|c|c|c|c|c|c|c|c|}
\hline \multirow[t]{2}{*}{ No } & \multirow[t]{2}{*}{ Guru } & \multicolumn{4}{|c|}{ Aspek yang dinilai } & \multirow{2}{*}{$\begin{array}{l}\text { Jml } \\
\text { Skor }\end{array}$} & \multirow[t]{2}{*}{ Kategori } \\
\hline & & $\mathrm{I}$ & 2 & 3 & 4 & & \\
\hline$T$ & Awun & 2 & 2 & 2 & $T$ & 7 & $B$ \\
\hline 2 & Suslen & 2 & 2 & $\mathrm{~T}$ & $\mathrm{~T}$ & 6 & $C$ \\
\hline 3 & Masniyah & 2 & 2 & 2 & 1 & 7 & C \\
\hline 4 & Umi Kalsum & 2 & 2 & 2 & $T$ & 7 & $\mathrm{C}$ \\
\hline 5 & Anis Soini & 2 & 2 & 2 & $\mathrm{I}$ & 7 & $C$ \\
\hline 6 & Yunina Novarita & 2 & 2 & 2 & $T$ & 7 & $C$ \\
\hline 7 & Amrullah & 2 & 2 & 2 & 1 & 7 & C \\
\hline 8 & Reny Alfionita & 2 & 2 & $\mathrm{~T}$ & $\mathrm{~T}$ & 6 & $C$ \\
\hline 9 & Evi Saputri & 2 & 2 & $\mathrm{I}$ & $\mathrm{I}$ & 6 & C \\
\hline 10 & Dwi Suryanti & 2 & 2 & $\mathrm{~T}$ & $\mathrm{~T}$ & 6 & $C$ \\
\hline
\end{tabular}

Keterangan:

\begin{tabular}{|l|l|}
\hline No & \multicolumn{1}{|c|}{ Aspek yang dinilai } \\
\hline I & $\begin{array}{l}\text { Guru menyusun silabus dengan format yang terdiri dari 9 aspek yaitu } \\
\text { mapel, KD, kegiatan pembelajaran, sumber belajar, penilaian, jenis } \\
\text { daring, alokasi waktu, ketercapaian pembelajaran, dan kendala }\end{array}$ \\
\hline $\mathbf{2}$ & $\begin{array}{l}\text { Pada aspek kegiatan pembelajaran, guru mampu menyusun kegiatan } \\
\text { berupa pembelajaran dengan moda daring }\end{array}$ \\
\hline 3 & $\begin{array}{l}\text { Pada aspek jenis daring guru mampu mencantumkan jenis aplikasi yang } \\
\text { di gunakan dalam moda daring }\end{array}$ \\
\hline 4 & Guru mampu menyusun silabus daring secara sistematis \\
\hline
\end{tabular}
A : Amat Baik (Skor 3)
B: Baik (Skor 2)
C: Cukup (Skor I)

Skor Maksimal: $3 \times 4=12$

Kriteria Penilaian

A: 9-12: Kemampuan guru dalam pengembangan silabus daring Amat Baik

B:5-8 : Kemampuan guru dalam pengembangan silabus daring Baik

$\mathrm{C}: \leq 4$ : Kemampuan guru dalam pengembangan silabus daring Cukup

Sedangkan penilaian pembelajaran inovatif model lingkungan sekitar sebagai sumber belajar dalam kegiatan pembelajaran di kelas pada siklus I didapatkan hasil sebagai berikut:

Tabel 6 Data Hasil Penilaian Kemampuan Guru dalam Pengembangan RPP daring Siklus I

\begin{tabular}{|c|c|c|c|c|c|c|}
\hline \multirow[t]{2}{*}{ No } & \multirow[t]{2}{*}{ Nama Guru } & \multicolumn{4}{|c|}{ Aspek yang di nilai } & \multirow[t]{2}{*}{ Kategori } \\
\hline & & I & 2 & 3 & 4 & \\
\hline I & Awun & 2 & 2 & I & I & B \\
\hline 2 & Suslen & 2 & 2 & 2 & $\mathrm{I}$ & B \\
\hline 3 & Masniyah & 2 & 2 & 2 & $\mathrm{I}$ & $\mathrm{B}$ \\
\hline 4 & Umi Kalsum & 2 & 2 & 2 & $\mathrm{I}$ & $\mathrm{B}$ \\
\hline 5 & Anis Soini & 2 & 2 & 2 & $\mathrm{I}$ & B \\
\hline 6 & Yunina Novarita & 2 & 2 & 2 & $\mathrm{~T}$ & $\mathrm{~B}$ \\
\hline 7 & Amrullah & 2 & 2 & 2 & $\mathrm{I}$ & B \\
\hline 8 & Reny Alfionita & 2 & 2 & 2 & $\mathrm{I}$ & $\mathrm{B}$ \\
\hline 9 & Evi Saputri & 2 & 2 & 2 & $\mathrm{I}$ & B \\
\hline 10 & Dwi Suryanti & 2 & 2 & 2 & $\mathrm{I}$ & $\mathrm{B}$ \\
\hline \multicolumn{2}{|c|}{ Nilai rata-rata } & 2 & 2 & I,7 & I & \\
\hline
\end{tabular}

Keterangan:

\begin{tabular}{|c|c|}
\hline No & Aspek yang dinilai \\
& \\
\hline
\end{tabular}




\begin{tabular}{|l|l|}
\hline I & $\begin{array}{l}\text { Guru menyusun RPP dengan format yang terdiri dari 8 aspek yaitu KD, } \\
\text { Indikator, Tujuan pembelajaran, materi pembelajaran, model } \\
\text { pembelajaran, Alat, bahan dan media, langkah kegiatan dan penilaian }\end{array}$ \\
\hline 2 & $\begin{array}{l}\text { Pada aspek langkah kegiatan, guru mampu menyusun kegiatan berupa } \\
\text { pembelajaran dengan moda daring }\end{array}$ \\
\hline 3 & $\begin{array}{l}\text { Pada aspek penilaian guru mampu menyusun instrument penilaian yang } \\
\text { di gunakan dalam moda daring }\end{array}$ \\
\hline 4 & Guru mampu menyusun RPP daring secara sistematis \\
\hline
\end{tabular}
A : Amat Baik (Skor 3)
B: Baik (Skor 2)
C: Cukup (Skor I)

Skor Maksimal: $3 \times 4=12$

Kriteria Penilaian

A: 9- 12 : Kemampuan guru dalam pengembangan RPP daring Amat Baik

B:5-8 : Kemampuan guru dalam pengembangan RPP daring Baik

$C: \leq 4$ : Kemampuan guru dalam pengembangan RPP daring Cukup

\section{Diagram 2 Hasil Penilaian Kemampuan Guru dalam Pengembangan RPP daring Siklus I}

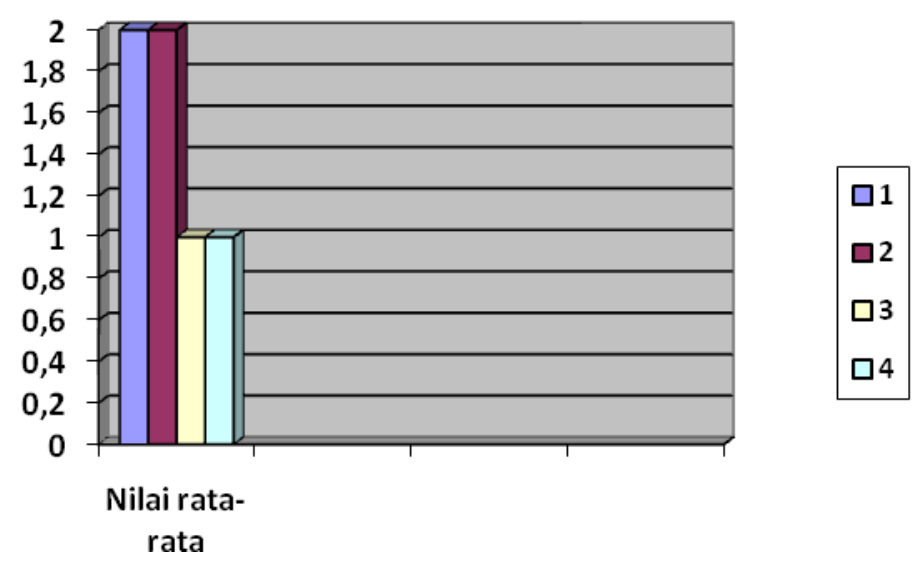

\section{c. Refleksi}

Data penelitian tindakan sekolah yang diperoleh dari hasil observasi kemampuan guru dalam pengembangan RPP daring pada siklus I, hasilnya termasuk katagori "baik" dengan rata-rata aspek I yakni 2, aspek 2 yakni 2, aspek 3 yakni I,7, dan aspek 4 yakni I. Hal ini menunjukkan bahwa kemampuan guru dalam pengembangan RPP daring sudah baik, akan tetapi perlu peningkatan.

Dengan adanya hasil observasi dan penilaian pada kegiatan siklus I maka peneliti melakukan refleksi. Dari refleksi terhadap seluruh kegiatan pada siklus I, maka refleksi pada siklus I adalah sebagai berikut:

a) Guru sangat baik dalam memperhatikan materi pembinaan,

b) Guru sudah dapat bekerja sama dengan kelompoknya,

c) Tidak ada egoisme Guru d) Guru sudah memahami dan mengusai materi pengembangan silabus dan RPP daring.

Adapun hasil pengamatan penelitian dari teman sejawat kepada peneliti pada siklus I ditemukan hal-hal sebagai berikut :

a) Pembentukan kelompok terencana dengan baik berdasarkan pangkat, golongan ruang dan kesetaraan jender

b) Peneliti menjelaskan dengan baik cara-cara bekerja dalam kelompok.

c) Peneliti dalam memberikan dampingan selama melakukan pembinaan merata.

d) Peneliti memberikan motivasi pada guru untuk dapat aktif dalam kegiatan pembinaan.

\section{B. Pembahasan}

Berdasarkan hasil analisis dan pembahasan siklus I dan siklus II tersebut di atas, maka dapat disimpulkan bahwa: Ada peningkatan kemampuan guru dalam pengembangan silabus dan RPP daring. 
Hasil pembinaan pra tindakan tentang kemampuan guru dalam pengembangan silabus dan RPP daring di dapatkan data bahwa para guru masih kesulitan dalam mengembangkan silabus dan RPP daring, karena selama ini pembelajaran masih membutuhkan ruang kelas sebagai tempat tatap muka, pelaksanaan pembelajaran dimasa pandemi mengharuskan guru menggunakan aplikasi agar bisa di gunakan siswa secara daring, sedangkan guru dalam menggunakan aplikasi daring juga masih belajar dan jaringan internet yang lemah menjadikan salah satu kendala pengimplementasian pelaksanaan pembelajaran dimasa pandemi.

Pada pra tindakan kemampuan guru dalam pengembangan silabus dan RPP daring, hal ini di tunjukkan oleh data Hasil penilaian kemampuan guru dalam pengembangan silabus dan RPP daring Pra Tindakan yang masih rendah.

Data penelitian tindakan sekolah yang diperoleh dari hasil observasi kemampuan guru dalam pengembangan RPP daring pada siklus I, hasilnya termasuk katagori "baik" dengan rata-rata aspek I yakni 2, aspek 2 yakni 2, aspek 3 yakni I,7, dan aspek 4 yakni I. Hal ini menunjukkan bahwa kemampuan guru dalam pengembangan RPP daring sudah baik, akan tetapi perlu peningkatan.

Dengan adanya hasil observasi dan penilaian pada kegiatan siklus I maka peneliti melakukan refleksi. Dari refleksi terhadap seluruh kegiatan pada siklus I, maka refleksi pada siklus I adalah sebagai berikut:

a) Guru sangat baik dalam memperhatikan materi pembinaan,

b) Guru sudah dapat bekerja sama dengan kelompoknya,

c) Tidak ada egoisme Guru

d) Guru sudah memahami dan mengusai materi pengembangan silabus dan RPP daring.

\section{PENUTUP}

\section{A. Kesimpulan}

Berdasarkan hasil analisis dan pembahasan siklus I dan siklus II tersebut di atas, maka dapat disimpulkan bahwa: Ada peningkatan kemampuan guru dalam pengembangan silabus dan RPP daring.

Hasil pembinaan pra tindakan tentang kemampuan guru dalam pengembangan silabus dan RPP daring di dapatkan data bahwa para guru masih kesulitan dalam mengembangkan silabus dan RPP daring, karena selama ini pembelajaran masih membutuhkan ruang kelas sebagai tempat tatap muka, pelaksanaan pembelajaran dimasa pandemi mengharuskan guru menggunakan aplikasi agar bisa di gunakan siswa secara daring, sedangkan guru dalam menggunakan aplikasi daring juga masih belajar dan jaringan internet yang lemah menjadikan salah satu kendala pengimplementasian pelaksanaan pembelajaran dimasa pandemi.

Pada pra tindakan kemampuan guru dalam pengembangan silabus dan RPP daring, hal ini di tunjukkan oleh data Hasil Penilaian Kemampuan Guru dalam Pengembangan RPP daring Pra Tindakan

Data penelitian tindakan sekolah yang diperoleh dari hasil observasi kemampuan guru dalam pengembangan RPP daring pada siklus I, hasilnya termasuk katagori "baik" dengan rata-rata aspek I yakni 2, aspek 2 yakni 2, aspek 3 yakni I,7, dan aspek 4 yakni I. Hal ini menunjukkan bahwa kemampuan guru dalam pengembangan RPP daring sudah baik, akan tetapi perlu peningkatan.

Dengan adanya hasil observasi dan penilaian pada kegiatan siklus I maka peneliti melakukan refleksi. Dari refleksi terhadap seluruh kegiatan pada siklus I, maka refleksi pada siklus I adalah sebagai berikut:

a) Guru sangat baik dalam memperhatikan materi pembinaan,

b) Guru sudah dapat bekerja sama dengan kelompoknya,

c) Tidak ada egoisme Guru

d) Guru sudah memahami dan mengusai materi pengembangan silabus dan RPP daring.

\section{B. Saran}

Peneliti membuat saran-saran berikut:

I. Untuk Guru

Dengan meningkatkan kemampuan guru dalam pengembangan silabus dan RPP daring sudah tentu akan membawa dampak positif baik bagi diri guru sendiri dan juga bagi para siswa.

2. Untuk Para Kepala sekolah

Bagi para Kepala sekolah teruslah mencari dan menerapkan program-program yang pas dan cocok untuk memperbaiki kualitas pengajar di sekolah. Hal ini akan menunjang sekali pada tercapainya tujuan pembelajaran.

\section{Bagi kalangan umum}

Bagi kalangan umum bisa membaca dan menjadikan refrensi hasil tulisan saya ini untuk memilih 
metode dalam meningkatkan Kemampuan guru dalam pengembangan silabus dan RPP daring.

\section{DAFTAR PUSTAKA}

Arikunto, Manajemen Pendidikan, Yogyakarta: Aditya Media, 2009

Arikunto, Suharsimi, 2004, Dasar-dasar Supervisi, Jakarta, PT. Rineka Cipta.

Buku Materi Bafadal, I. 2006. Peningkatan Profesionalisme Guru Sekolah Dasar. Jakarta: Bumi Aksara.

Departemen Pendidikan dan Kebudayaan, 1995. Pedoman Pembinaan Profesional Sekolah Dasar. Dikdasmen: Jakarta

Departemen Pendidikan Nasional, 2008. Petunjuk TeknisPenelitian Tindakan Sekolah. Dirjen PMTK: Jakarta.

Depdiknas. 2005. Kamus Besar Bahasa Indonesia Edisi Ke 3. Jakarta: Balai Pustaka.

Gentry, C. G. 1994. Introduction to instructional development: Process and technique. Belmont, CA: Wadsworth Publishing Company.

Jauhari. 2019. Penerapan Metode Pembelajaran Kooperatif Tipe Number Head Together (NHT) Pada Siswa Kelas XI IPS 2 SMA Negeri 2 Watampone Untuk Meningkatkan Hasil Belajar Bahasa Indonesia. JIKAP PGSD, 3 (I): 25-34.

Lundgren, Linda. 1994. Cooperative Learning in The Science Classroom. New York: Gleoncoe Maemillan Mc Graw Hill.

Muslich, Mansur. 2007, Pembelajaran Berbasis Kompetensi dan Kontektual. Jakarta: Bumi Aksara

Pandong, A. (2003). Jabatan Fungsional Pengawas. Badan Diklat Depdagri \& Diklat Depdiknas. 